\title{
The Biology and Chemistry of the Compositae
}

\section{edited by V. H. Heywood, J. B. Harborne and B. L. Turner}

Volume 1 0.12.346801.9 The Compositae is a large family which contains a number of economically important plants and from which many valuable plant products have been obtained. However no overall resumé has been attempted until now because of its complexity. The contributors to this

Volume $2 \quad 0.12 .346802 .7$ book, all of whom have carried out significant research on the group in recent years, have presented their findings in a form which provides the first fully comprehensive survey of both the systematics and comparative biochemistry of the Compositae, which is

February/March 1978

$1200 \mathrm{pp}$. in toto complete at the generic level. Not only is each tribe given detailed individual consideration, but in addition there is a unique collection of general reviews on the

$£ 27.50 / \$ 53.75$ per volume biology and chemistry of the Family as a whole.

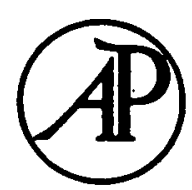

\section{Academic Press}

London New York San Francisco

A Subsidiary of Harcourt Brace Jovanovich, Publishers

24-28 Oval Road, London NW1, England

111 Fifth Avenue, New York, NY 10003, USA 


\section{Journal of Reproduction \& Fertility}

Volume 52 (No. 1), January 1978

L. R. Fraser \& I. Maudlin. Relationship between sperm concentration and the incidence of polyspermy in mouse embryos fertilized in vitro

I. Maudlin \& L. R. Fraser. The effect of sperm and egg genotype on the incidence of chromosomal anomalies in mouse embryos fertilized in vitro

C. M. Hetherington $\& \mathbf{H}$. Fowler. Effect of tolerance to paternal antigens on placental and fetal weight in the mouse

N. S. Fechheimer \& R. G. Jaap. The parental source of heteroploidy in chick embryos determined with chromosomally marked gametes

\section{Volume 52 (No. 2), March 1978}

J. S. Sobel \& L. Nebel. Changes in Concanavalin A agglutinability during development of the inner cell mass and trophoblast of mouse blastocysts in vitro

\section{Also, Symposium Reports 9 and 10 which appeared in Volume 51, September 1977}

No. 9: OvULATION

S. S. C. Yen. Regulation of the hypothalamic-pituitary-ovarian axis in women

E. Diczfalusy. Interrelations between plasma levels of biologically active $\mathrm{LH}$ and ovarian and adrenal steroids in the normal menstrual cycle

I. D. Cooke, E. A. Lenton, M. Adams, M. A. Pearce, D. Fahmy \& C. R. Evans. Some clinical aspects of pituitary-ovarian relationships in women with ovulatory infertility

H. R. Lindner, A. Amsterdam, Y. Salomon, A. Tsafriri, A. Nimrod, S. A. Lamprecht, U. Zor \& Y. Koch. Intraovarian factors in ovulation: determinants of follicular response to gonadotrophins

R. G. Edwards, R. E. Fowler, R. E. Gore-Langton, R. G. Gosden, E. C. Jones, C. Readhead \& P. C. Steptoe. Normal and abnormal follicular growth in mouse, rat and human ovaries Available as a composite offprint, $£ 3.50$ (U.S. \$7.00)

NO. 10: NEWER ASSAY TECHNIQUES

S. L. Jeffcoate. Recent developments in steroid radioimmunoassays

G. V. Groom. The measurement of human gonadotrophins by radioimmunoassay

L. Bitensky. Cytochemical bioassays of polypeptide hormones

D. Schulster. Radioreceptor assays: plasma membrane receptors and assays for polypeptide and glycoprotein hormones

D. S. Millington. New techniques in quantitative mass spectrometry

Available as a composite offprint, $£ 2.00$ (U.S. $\$ 4.00$ )

The Journal of Reproduction and Fertility is published every 2 months at $£ 14.00$ (U.S. $\$ 30.00$ ) per issue; annual subscription $f 70.00$ (U.S. $\$ 150.00$ ), by the

JOURNALS OF REPRODUCTION AND FERTILITY LTD P.O. Box 32, Commerce Way, Colchester CO2 8HP, U.K. 


\section{GENETICAL RESEARCH}

VOLUME 31, NUMBER 2, APRIL 1978

\section{CONTENTS}

GREWAL, MANJIT SINGH. Skeletal polymorphism and genetic drift in a

Delhi frog, Rana cyanophlictis - a follow-up study

FREELING, MICHAEL and CHENG, DAVID S. K. Radiation-induced alcohol dehydrogenase mutants in maize following allyl alcohol selection of pollen

TYPAS, MILTON A. and HEALE, JAMES B. Heterozygous diploid analyses via the parasexual cycle and a cytoplasmic pattern of inheritance in Verticillium spp.

JOSEFOWICZ, WENDY J. and HARDY, MARGARET H. The expression of the gene asebia in the laboratory mouse. 2. Hair follicles

JOSEFOWICZ, WENDY J. and HARDY, MARGARET H. The expression of the gene asebia in the laboratory mouse. 3. Sebaceous glands

BRODA, PAUL and COLLINS, J. F. Role of simple and complex aggregates in Escherichia coli $\mathrm{Hfr} \times \mathrm{F}^{-}$matings

LUSH, I. E. and ANDREWS, KATHRYN M. Genetic variation between mice in their metabolism of coumarin and its derivatives

YANNOPOULOS, GEORGE. Studies on male recombination in a Southern

Greek Drosophila melanogaster population

MOLNÁR, J., BÉLÁDIE, E. and HOLLAND, I. B. The plasmid curing action of imipramine in Escherichia coli $\mathrm{K} 12$

malHотr A, K. с. Natural selection and colour blindness: fresh data on Indian castes

\section{CAMBRIDGE UNIVERSITY PRESS}

The Pitt Building, Trumpington Street, Cambridge CB2 1RP

Bentley House, 200 Euston Road, London NW 12 DB

32 East 57th Street, New York, N.Y.10022 